\title{
Peramalan Data Ekspor Non Migas Provinsi Kalimantan Timur Menggunakan Univariate Time Series
}

\author{
Farida Nur Hayati ${ }^{(1)}$, Diana Nurlaily ${ }^{(2)}$, Elly Pusporani ${ }^{(3)}$ \\ Institut Teknologi Kalimantan \\ Jl. Soekarno Hatta Km. 15 Karang Joang, Telp./Fax. 0542-8530800, Balikpapan Kalimantan \\ Timur, 76127 \\ e-mail: farida.nur@lecturer.itk.ac.id, diana.nurlaily@lecturer.itk.ac.id,_elly.pusporani@gmail.com
}

\begin{abstract}
ABSTRAK
Kegiatan ekspor sangat penting untuk mengetahui jenis perekonomian negara dikatakan perekonomian terbuka atau tertutup. Semakin tinggi nilai ekspor suatu negara maka akan semakin terbuka perekonomiannya. Kegiatan ekspor juga menjadi penggerak perekonomian suatu negara. Mengingat pentingnya hal tersebut maka, diperlukan kebijaksanaan meningkatkan nilai ekspor khususnya pada komoditi non migas. Komoditi non migas dipilih pada penelitian ini karena adanya kemerosotan harga minyak bumi di pasaran dunia. Sehingga untuk mengatasi ketergantungan penerimaan negara yang berasal dari minyak dan gas bumi maka pemerintah berusaha meningkatkan ekspor komoditi dan jasa-jasa non migas. Kondisi ekspor luar negeri Kalimantan Timur didominasi oleh ekspor non migas. Oleh karena itu, prediksi atau peramalan nilai dari komoditas ekspor non migas di Kalimantan Timur dapat digunakan untuk mengetahui devisa/ sejumlah uang pada lingkup internasional yang akan diperoleh, agar dapat digunakan sebagai bahan pertimbangan dalam menentukan kebijakan oleh pemerintah. Pada penelitian ini, untuk meramalkan nilai ekspor non migas digunakan metode Autoregresif Integrated Moving Average (ARIMA). Langkah pertama dalam melakukan analisis metode tersebut adalah identifikasi model dengan cara melihat ACF dan PACF, selanjutnya melakukan penaksiran serta uji signifikansi parameter, setelah itu dilakukan diagnostic checking, dan yang terakhir adalah peramalan/prediksi. Hasil penelitian peramalan data ekspor menggunakan ARIMA menunjukkan bahwa model ARIMA yang paling baik dalam meramalkan data ekspor non migas di Kalimantan Timur berdasarkan nilai sMAPE, dan RMSE adalah ARIMA $(0,1,[1,12])$.
\end{abstract}

Kata kunci : Ekspor, Ekspor non migas, ARIMA, RMSE, sMAPE

\begin{abstract}
Exports are very important to know the type of economy a country can be said to be open or closed economy. The higher the export value of a country, the more open the economy will be. Export activities are also a driver of a country's economy. Given the importance of this, discretion is needed in increasing exports, especially non-oil and gas commodities. Non-oil and gas commodities were chosen in this study because of the slump in petroleum prices in the world market. So as to overcome the dependence on state revenues derived from oil and gas, the government seeks to increase exports of commodities and non-oil and gas services. East Kalimantan's overseas export conditions are dominated by non-oil and gas exports. Therefore, prediction or forecasting of the value of non-oil and gas export commodities in East Kalimantan can be used to determine foreign exchange / amount of money in the international sphere to be obtained, so that it can be used as a consideration by the government to determine policy. In this study the method used to predict the value of non-oil and gas exports is Autoregresive Integrated Moving Average (ARIMA). The first step in analyzing ARIMA method is to identify the model by looking at ACF and PACF, then perform the assessment and parameter significance test, after that diagnostic checking parameter is obtained, and the last is forecasting/ prediction. The results of export data forecasting using ARIMA show that ARIMA model is best to forecast non-oil and gas export data in East Kalimantan based on SMAPE value, and RMSE is ARIMA $(0.1,[1,12])$.
\end{abstract}

Keywords : Non-oil and gas Export, ARIMA, RMSE, sMAPE

Farida Nur Hayati ${ }^{1}$, Diana Nurlaily ${ }^{2}$, Elly Pusporani ${ }^{3} /$

J Statistika Vol. 14, No. 2, (2021) 


\section{PENDAHULUAN}

Kegiatan ekspor sangat penting untuk mengetahui jenis perekonomian negara bisa dikatakan perekonomian terbuka atau tertutup. Semakin tinggi nilai ekspor suatu negara maka akan semakin terbuka perekonomiannya. Kegiatan ekspor juga menjadi penggerak perekonomian suatu negara. Hal ini membuat antar negara berusaha melakukan peningkatan kuantitas dan kualitas ekspornya agar laku dan lebih efisien di pasar Internasional (Badan Pusat Statistika, 2020). Perekonomian berbasis ekspor mempunyai kelebihan diantaranya adalah: kegiatan ekspor, dapat menyerap tenaga kerja, selain itu, dapat menghasilkan cash inflow berupa valuta asing sebagai bentuk pembayaran atas produk yang dijual ke luar negeri, terutama untuk ekspor non migas, kegiatan ekspor juga dapat memudahkan suatu negara untuk mencapai kemandiriannya dalam perekonomian (Wardhana, 2011). Karenanya diperlukan analisis untuk membuat suatu kebijaksanaan dalam meningkatkan nilai ekspor suatu barang khususnya komoditi non migas. Komoditi non migas tersebut dipilih karena adanya penurunan harga minyak bumi di pasaran dunia. Sehingga untuk mengatasi ketergantungan penerimaan negara yang berasal dari minyak dan gas bumi maka pemerintah berusaha meningkatkan ekspor komoditi dan jasa-jasa non migas (Huda, 2006). Menurut Bank Indonesia (2009), sektor non migas adalah sektor yang memberikan sumbangan devisa terbesar untuk Indonesia. Selama periode 2013-2020, peranan ekspor nonmigas di Indonesia mencapai kisaran angka $82 \%$ sampai $94 \%$, sedangkan peranan ekspor migas berkisar antara 5\% sampai 17\% (Badan Pusat Statistika, 2020).

Komoditas sektor non migas dibagi menjadi kelompok dagangan umum dan kelompok barang lainnya seperti emas nonmoneter. Kelompok barang dagangan umum meliputi pertanian, sektor industry, sektor pertambangan dan sektor barang lainnya (Lestari, Widiharih, \& Rahmawati, 2018). Di Kalimantan Timur, Komoditi ekspornya didominasi oleh komoditi ekspor batu bara dan turuanannya, diikuti oleh produksi cpo dan sebagainnya. Hal ini menunjukkan bahwa di Kalimantan Timur, ekspor non migas merupakan penyumbang terbesar nilai ekspor. Berdasarkan perkembangan ekspor non migas di Kalimantan Timur tahun 2011 sampai tahun 2017, pada tahun 2014 terjadi penurunan jumlah ekspor non migas yang tinggi jika dibandingkan jumlah ekspor pada tahun 2013. Penurunan jumlah ekspor non migas terus terjadi sampai tahun 2016, dimana tahun 2017 jumlah ekpsor non migas di Kalimantan Timur sudah mulai meningkat. Penurunan jumlah ekspor non migas ini disebabkan adanya pembatasan ekspor batu bara oleh pemerintah pusat (Nurmawaddah, 2019).

Prediksi atau peramalan nilai dari komoditas ekspor non migas di Kalimantan Timur dapat digunakan untuk mengetahui devisa /sejumlah uang pada lingkup internasional yang akan diperoleh sebagai bahan pertimbangan oleh pemerintah untuk menentukan kebijakan. Berdasarkan hal tersebut, diperlukan metode analisis yang tepat untuk mendapatkan prediksi data yang paling sesuai. Banyak penelitian berkaitan peramalam ekspor pernah dikaji sebelumnya diantaranya oleh Ruslan, Harahap, dan Sembiring pada tahun 2013 untuk meramalkan nilai ekspor di Provinsi Sumatera utara dengan menggunakan metode ARIMA Box Jenkins, dan menghasilkan model ARIMA $(1,0,1)$. Amalina, (2019), juga pernah melakukan penelitian dengan meramalkan nilai ekspor migas dan non migas menggunakan Artificial Neural yang menghasilkan parameter yang paling optimal untuk meramalkan data ekspor dengan MAPE bernilai baik. Lestari, dkk (2018), juga meramalkan ekspor non migas menggunakan kalender variansi islam, dimana berdasarkan analisis didapatkan data ekspor non migas terdapat trend, pola musiman sehingga menggunakan model ARIMA. Pada penelitian ini, metode yang digunakan untuk melakukan forecast/peramalan data ekspor non migas adalah Autoregressif Integrated Moving Average (ARIMA). ARIMA merupakan salah satu metode yang digunakan untuk meramal suatu variabel dengan cepat, akurat dan sederhana. Langkah pertama dalam melakukan analisis metode ARIMA adalah mengidentifikasi model dengan cara melihat ACF dan PACF, selanjutnya melakukan penaksiran parameter serta uji signifikansi, setelah itu dilakukan diagnostic checking, dan yang terakhir adalah peramalan/prediksi. Banyak penelitian yang berkaitan dengan metode ARIMA salah satunya yaitu Hartati (2017) yang meneliti tentang peralaman pergerakan laju inflasi dengan metode ARIMA. Hasil penelitian menunjukan bahwa hasil ramalan menggunakan metode ARIMA mampu mengikuti pergerakan data actual laju inflasi. Berdasarkan hasil uraian tersebut, pada penelitian ini akan dilakukan peramalan nilai ekspor non migas yang ada di Kalimantan Timur menggunakan Metode ARIMA Box Jenkins. Diharapakan penelitian ini dapat memberikan informasi terkait prediksi nilai ekspor non migas di Kalimantan Timur sehingga dapat digunakan pemerintah dalam

Farida Nur Hayati ${ }^{1}$, Diana Nurlaily ${ }^{2}$, Elly Pusporani ${ }^{3} /$

J Statistika Vol. 14, No. 2, (2021) 
mengambil kebijakan untuk meningkatkan ekspor di Kalimantan Timur.

\section{METODE PENELITIAN \\ 2.1 ARIMA}

Autoregressive Integrated Moving Average adalah salah satu metode peramalan/prediksi untuk data time series. Metode ini biasa disebut dengan ARIMA. Berdasarkan Wei (2006) model $\operatorname{ARIMA}(\mathrm{p}, \mathrm{d}, \mathrm{q})$ dapat dituliskan sebagai berikut:

dimana

$$
\phi_{p}(B)(1-B)^{d} Z_{t}=\theta_{q}(B) a_{t}
$$

$(p, d, q) \quad: \mathrm{p}$ menyatakan orde $\mathrm{AR}$ (Autoregressive), q menyatakan orde MA (Moving Average) dan d menyatakan differencing untuk data yang bukan musiman

$\phi_{p}(B) \quad$ : koefisien AR dengan orde $p$ dimana $\phi_{p}(B)=1-\phi_{1}(B)-$ $\phi_{2}\left(B^{2}\right)-\cdots-\phi_{p}\left(B^{p}\right)$

$\theta_{q}(B) \quad$ : koefisien MA dengan orde $q$ dimana $\theta_{q}(B)=1-\theta_{1}(B)-\theta_{2}\left(B^{2}\right)-$ $\cdots-\theta_{q}\left(B^{q}\right)$

$(1-B)^{d} \quad$ : differencing orde $d$

$a_{t} \quad$ : nilai residual di $\mathrm{t}$

Dalam menggunakan metode ARIMA terdapat syarat yang harus terpenuhi yaitu data penelitian harus Stasioner terhadap varians dan means. Setelah data telah memenuhi syarat tersebut, baru analisis menggunakan metode ARIMA dapat digunakan. Berdasarkan Box \& Jenkins diperlukan empat langkah dalam menganalisis data dengan metode ARIMA yaitu:

1. Mengidentifikasi Model

Dalam tahapan ini dilakukan identifikasi Model Awal ARIMA. Langkah Awal yang dilakukan yaitu pengecekan stasioneritas data kemudian dilakukan pengecekan orde AR atau MA dari data dengan menggunakan ACF yang merupakan kepanjangan dari "Autocorrelation Function" dan PACF "Partial Autocorrelation Function". ACF adalah ukuran korelasi antara $Z_{t}$ dan $Z_{t+k}$ pada data sedangkan PACF adalah ukuran korelasi antara $Z_{t}$ dan $Z_{t+k}$ setelah mendapat pengaruh dependensi linier pada variabel yang mengintervesi variabel $Z_{t+1}, Z_{t+2}, \ldots, Z_{t+k-1}$ dihilangkan (Wei, 2006):

2. Mengestimasi Parameter
Pada tahap ini nilai parameter akan ditentukan dengan melakukan estimasi model awal. OLS (Ordinary Least Square), MLE (Maximum Lekelihood Estimation) dan lain-lain adalah beberapa metode estimasi yang bisa digunakan. Selanjutnya dilakukan uji untuk memeriksa signifikansi, untuk mengetahui apakah parameter yang ditaksir sudah signifikan atau belum. Hipotesis dari uji signifikansi ini adalah sebagai berikut (Wei, 2006):

$\mathrm{H}_{0}: \phi_{p}=0$ atau $\theta_{q}=0$

$\mathrm{H}_{1}: \phi_{p} \neq 0$ atau $\theta_{q} \neq 0$

Statistik Uji :

$$
t=\frac{\widehat{\phi}_{p}}{S E\left(\widehat{\phi}_{p}\right)} \text { atau } t=\frac{\widehat{\theta}_{q}}{S E\left(\widehat{\theta}_{q}\right)}
$$

Daerah Penolakan $\mathrm{H}_{0}$ adalah jika $|t|>t_{\frac{\alpha}{2}, n-p}$ dimana nilai $\mathrm{n}$ menunjukkan banyak observasi dari data time series dan $\mathrm{p}$ menunjukkan jumlah parameter suatu model.

3. Diagnostic Checking

Diagnostic Checking dalam ARIMA adalah pengecekan apakah aumsi residual yaitu White Noise dan Distribusi Normal terpenuhi. Pengujian asumsi white noise dapat dilakukan menggunakan pengujian Ljung-Box (Wei, 2006) dengan hipotesis sebagai berikut

$\mathrm{H}_{0}: \rho_{1}=\rho_{2}=\cdots=\rho_{k}=0$

$\mathrm{H}_{1}$ : minimal ada satu $\rho_{i} \neq 0$, untuk $i=1,2, \ldots, k$ Statistik Uji :

$$
Q=n(n+2) \sum_{i=1}^{k} \frac{\widehat{\rho}_{i}^{2}}{(n-i)}
$$

$\mathrm{H}_{0}$ akan ditolak apabila $Q>\chi_{\alpha, d f}^{2}$ atau nilai $p$-value $<\alpha$, dengan $d f=k-p-q$

Sedangkan untuk mengecekan asumsi distribusi normal digunakan uji menggunakan Kolmogorov Smirnov. Hipotesis dalam pengujian ini dapat diketahui sebagai berikut (Daniel, 1989) :

$\mathrm{H}_{0}: F(x)=F_{0}(x) \quad$ (residual dari data analisis berdistribusi normal)

$\mathrm{H}_{1}: F(x) \neq F_{0}(x)$ (residual dari data analisis tidak berdistribusi normal)

Statistik uji :

$$
D=\operatorname{Sup}\left|S(x)-F_{0}(x)\right|
$$

$\mathrm{H}_{0}$ akan ditolak apabila nilai $D>D_{(1-\alpha, n)}$ atau $p$ value $<\alpha$

4. $\quad$ Forecasting

Farida Nur Hayati ${ }^{1}$, Diana Nurlaily ${ }^{2}$, Elly Pusporani ${ }^{3} /$ 
Apabila parameter modelnya sudah signifikan dan memenuhi uji asumsi residual, maka tahapan forecast pada data dapat dilakukan.

\subsection{Kriteria Penentuan Model Terbaik}

Ukuran untuk menentukan model terbaik dalam melakukan peramalan/prediksi dapat menggunakan RMSE atau yang biasa disebut Root Mean Square Error dan sMAPE atau Symmetric Mean Absolute Percentage Error. Persamaan dari kedua metode tersebut adalah sebagai berikut (Gooijer \& Hyndman, 2006).

$$
\begin{gathered}
R M S E=\sqrt{\frac{1}{M} \sum_{t=1}^{M}\left(Z_{t}-\widehat{Z_{t}}\right)^{2}} \\
S M A P E=\sqrt{\frac{1}{M} \sum_{t=1}^{M} \frac{\left|Z_{t}-\widehat{Z_{t}}\right|}{1 / 2\left(Z_{t}+\widehat{Z_{t}}\right)} \times 100 \%}
\end{gathered}
$$

Dimana:

$$
\mathrm{M}=\text { banyak data out sample }
$$

$\mathrm{Z}_{\mathrm{t}}=$ Data penelitian pada waktu ke $\mathrm{t}$

$\widehat{\mathrm{Z}}_{\mathrm{t}}=$ Data hasil ramalan dari penelitian pada waktu ke $\mathrm{t}$

\subsection{Langkah Analisis}

Pada penelitian ini, digunakan data sekunder tentang Ekspor Non Migas di Kalimantan Timur pada bulan Januari 2011-Desember 2020 yang didapat dari website BPS Kalimantan Timur. Data kemudian dilakukan analisis menggunakan metode ARIMA Box Jenkins untuk tujuan peramalan/prediksi nilai ekspor non migas. Langkah analisis dari metode ARIMA dapat dijelaskan sebagai berikut:

1. Melakukan pembagian data menjadi data in sampel/ training pada Januari 2011 sampai Desember 2019 dan out sampel/testing pada Januari 2020 sampai Desember 2020.

2. Melakukan pemeriksaan stasioner data dalam varians. Jika tidak terpenuhi perlu dilakukan transformasi data.

3. Melakukan pemeriksaan stasioner data dalam mean. Jika tidak terpenuhi perlu dilakukan differencing.

4. Mengidentifikasi model dengan menggunakan plot ACF ddan PACF

5. Mengestimasi dan menguji parameter model ARIMA
6. Memeriksa asumsi white noise dan distribusi normal

7. Pemilihan model yang paling baik untuk melakukan peramalan/prediksi dengan menggunakan kriteria sMAPE dan RMSE

8. Melakukan forecast pada data Ekspor Non Migas di Kalimantan Timur

\section{HASIL DAN PEMBAHASAN}

Pada bab ini akan dibahas mengenai karakteristik dan peramalan/prediksi data Ekspor Non Migas di Kalimantan Timur.

\subsection{Karakteristik Data}

Berikut merupakan gambaran karakteristik dari data Ekspor Non Migas di Kalimantan Timur pada bulan Januari 2011-Desember 2020.

Tabel 1 Karakteristik Data

\begin{tabular}{|l|l|l|l|l|}
\hline Variabel & Mean & StDev & Minimum & Maximum \\
\hline Data & 1219.2 & 290.9 & 722.0 & 1927.3 \\
Ekspor & & & & \\
Non & & & & \\
Migas & & & & \\
\hline
\end{tabular}

Tabel 1 menunjukkan rata-rata nilai Ekspor Non Migas di Kalimantan Timur adalah sebesar \$ 1219,2 juta, dengan nilai maksimum sebesar \$ 1927,3 juta terjadi pada November 2012, dan minimum sebesar \$ 722.0 juta pada bulan September 2015. Selanjutnya akan disajikan boxplot untuk mengetahui fluktuasi nilai Ekspor Non Migas per tahun.

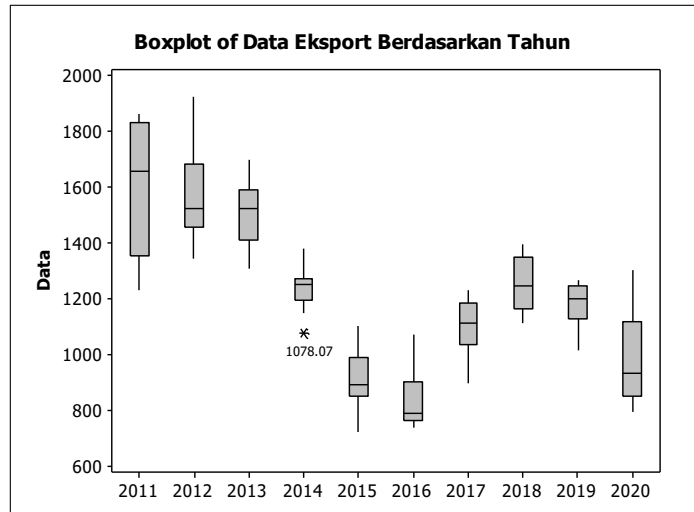

Gambar 1 Boxplot Data Per Tahun

Berdasarkan Gambar 1 diatas dapat diketahui bahwa nilai ekspor non migas di Kalimantan Timur pada tahun 2011-2016 semakin menurun, Data tersebut kemudian meningkat pada tahun-tahun

Farida Nur Hayati ${ }^{1}$, Diana Nurlaily ${ }^{2}$, Elly Pusporani ${ }^{3} /$

J Statistika Vol. 14, No. 2, (2021) 
berikutnya sampai 2018 dan menurun lagi pada tahun 2019, 2020. Menurut BPS Penurunan nilai ekspor luar negeri pada tahun 2019 adalah akibat adanya penurunan harga komoditas non migas seperti Harga Batubara Acuan (HBA). Sedangkan penurunan nilai ekspor non migas Provinsi Kalimantan Timur pada tahun 2020 dipengaruhi oleh turunnya sebagian besar nilai ekspor ke beberapa negara. Selanjutnya untuk mengetahui pola data tiap bulan, dilakukan visualisasi data yang digambarkan pada Gambar 2 berikut:

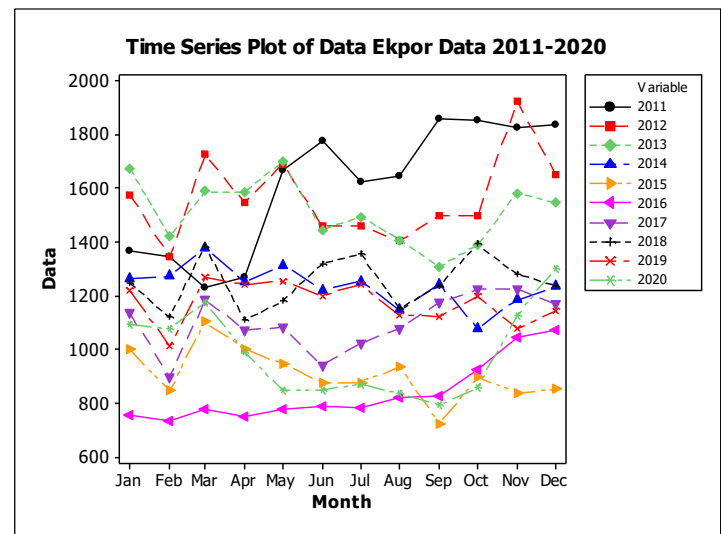

Gambar 2 Pola Data Ekpor Non Migas Per Bulan

Berdasarkan Gambar 2 dapat diketahui pola data ekspor non migas di Kalimantan Timur hampir sama di bulan Januari, Februari, Maret, dan April. Namun, Pada bulan April-Desember data ekspor non migas menunjukkan fluktuasi yang tidak menentu.

\subsection{Analisis Data Metode ARIMA}

Data Ekspor Non Migas di Kalimantan Timur dibagi menjadi dua, dengan pembagian data in sampel/training pada bulan Januari 2011 sampai Desember 2019 dan out sampel/testing pada Januari 2020 sampai Desember 2020. Selanjutnya data tersebut akan digambarkan dengan time series plot untuk mengetahui bentuk/pola datanya.

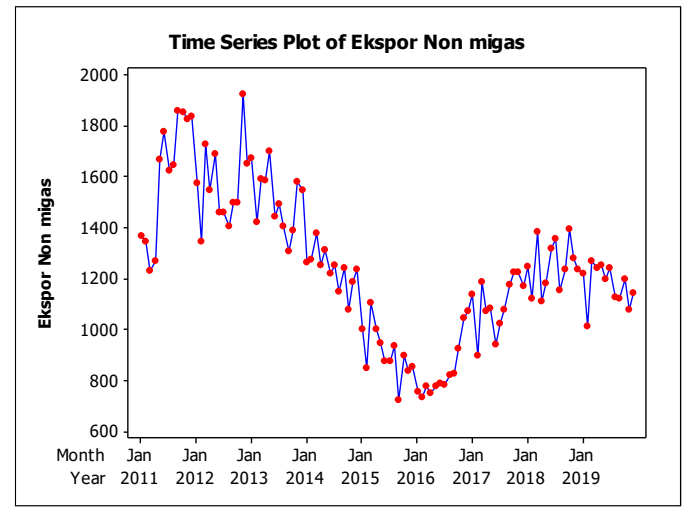

Gambar 3 Time Series Plot Data Ekpor Non Migas

Gambar 3 memperlihatkan bentuk/pola data Ekspor non migas di Kalimantan Timur yang menurun pada Januari 2011-Januari 2016. Data tersebut kemudian mengingkat pada Januari 2016Januari 2018 dan menurun kembali pada Januari 2019 dan 2020. Setelah melakukan visualisasi data untuk mengetahui pola data yang akan dianalisis, Langkah selanjutnya yaitu pemeriksaan kestasioneran data terhadap varians. Salah satu caranya adalah melakukan Transformasi Box-Cox yang disajikan pada Gambar 4 berikut:

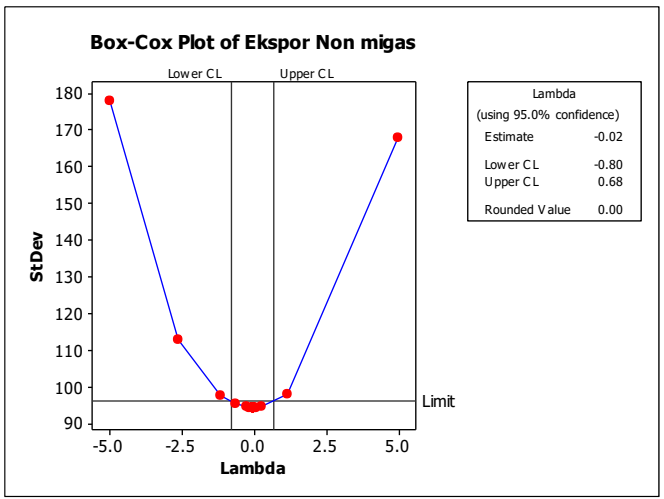

Gambar 4 Plot Box Cox Transformation Nilai Ekspor

Gambar 4 menunjukkaan bahwa data ekspor non migas di Kalimantan Timur ternyata belum stasioner terhadap varians karena nilai lower dan uppernya berada pada range -0.80 sampai 0,68 yang masih belum melewati 1 . Karena nilai tersebut belum melewati 1, maka transformasi logaritma natural perlu dilakukan pada data asli. Setelah dilakukan transformasi "ln" hasil yang didapat adalah:

Farida Nur Hayati ${ }^{1}$, Diana Nurlaily ${ }^{2}$, Elly Pusporani ${ }^{3} /$

J Statistika Vol. 14, No. 2, (2021) 


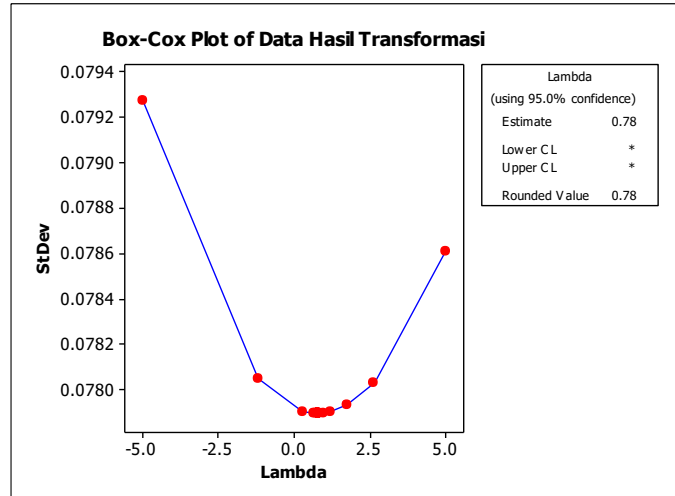

Gambar 5 Box Cox Data Transformasi

Gambar 5 menunjukkan bahwa data hasil transformasi yang telah dilakukan menggunakan fungsi logaritma natural, telah stasioner dalam varian. Hal tersebut terlihat dari nilai lower dan uppernya yang berada pada kisaran range $-\infty$ sampai $\infty$ (melewati 1). Karena data transformasi telah memenuhi asumsi stasioner terhadap varian, maka selanjutnya akan dilakukan pemeriksaan kestasioneran data terhadap means dengan menggunakan plot ACF. Hasil pemeriksaan dapat disajikan pada Gambar 6 berikut:

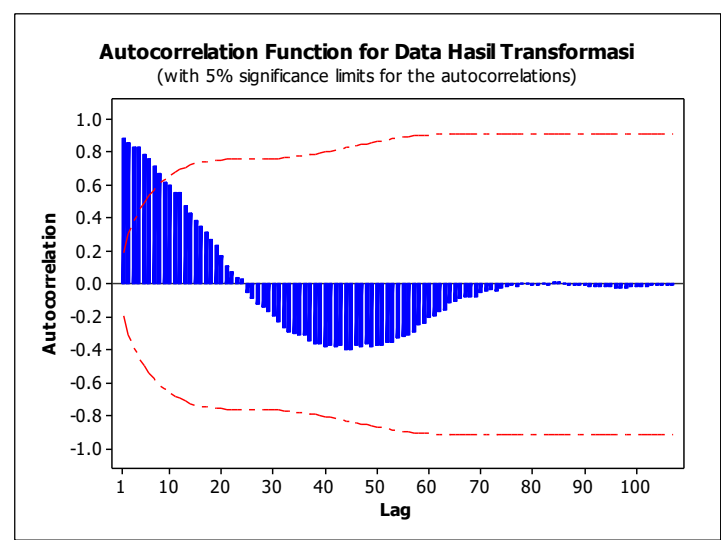

Gambar 6 ACF Data Transformasi

Berdasarkan hasil Plot ACF pada Gambar 6 maka plot ACF dari data yang dianalisis turun lambat/ terdapat proses penurunan pada lag 1,2,3, 4 yang tidak terlalu signifikan. Hal ini menunjukkan bahwa data yang dianalisis belum stasioner terhadap mean. Hasil tersebut didukung oleh pemeriksaan dengan pengujian Dickey Fuller yang menunjukkan PValue $(0.8138)$ yang $>$ dari $\alpha(0,05)$. Sehingga perlu dilakukan differencing 1 yang dapat disajikan pada Gambar berikut:

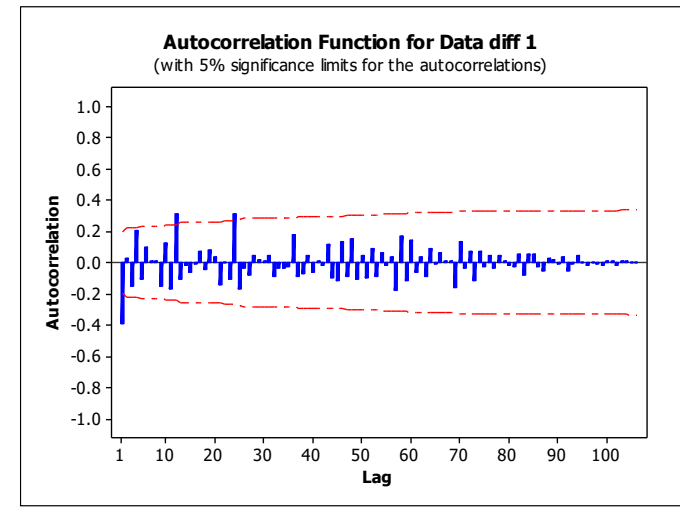

Gambar 7 ACF Data Differencing

Plot ACF pada Gambar 7 menunjukkan bahwa data telah stasioner terhadap mean. Hasil tersebut juga didukung oleh pemeriksaan menggunakan pengujian Dickey Fuller yang memiliki nilai PValue $(0.000)<\alpha(0,05)$. Sehingga data dapat dianalisis lebih lanjut untuk menentukan orde model ARIMA.

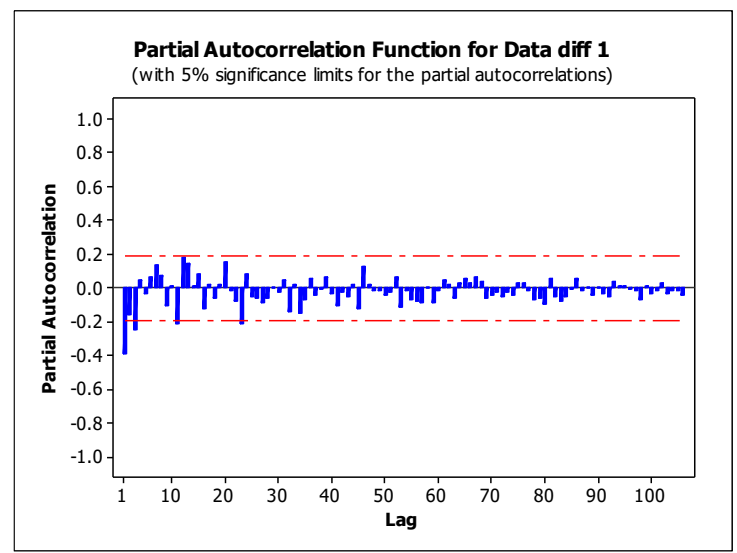

Gambar 8 PACF Data Differencing

Gambar 7 dan 8 menunjukkan bahwa Plot ACFnya cut off di Lag 1,12, dan 24 sedangkan PACF cut off di Lag 1,3,11,23 sehingga model ARIMA dugaan berdasarkan lag yang keluar adalah ARIMA $(0,1,[1,12])$ dan ARIMA $(1,1,[24])$. Selanjutnya dilakukan uji signifikansi untuk menentukan apakah parameter model ARIMA yang diduga signifikan atau tidak. Hasil uji signifikansi dapat disajikan pada Tabel berikut:

Table 2 Signifikansi Parameter

\begin{tabular}{|c|c|c|c|c|c|c|}
\hline $\begin{array}{c}\text { Model } \\
\text { ARIMA }\end{array}$ & Type & Coef & $\begin{array}{c}\text { SE } \\
\text { Coef }\end{array}$ & T & $\mathrm{P}$ & Kesimpulan \\
\hline $\left.\begin{array}{c}\text { ARIMA } \\
(0,1,[1,12 \\
]\end{array}\right)$ & $\theta_{1}$ & 0,48246 & 0.08112 & 5.95 & 0.000 & Signifikan \\
\cline { 2 - 7 } & $\theta_{12}$ & $-0,24697$ & 0.08370 & -2.95 & 0.004 & Signifikan \\
\hline
\end{tabular}

Farida Nur Hayati ${ }^{1}$, Diana Nurlaily ${ }^{2}$, Elly Pusporani ${ }^{3} /$ 


\begin{tabular}{|c|c|c|c|c|c|l|}
\hline \multirow{2}{*}{$\begin{array}{c}\text { ARIMA } \\
(1,1,[24])\end{array}$} & $\phi_{1}$ & -0.38331 & 0.09044 & -4.24 & $<0.000$ & Signifikan \\
\cline { 2 - 7 } & $\theta_{24}$ & -0.31264 & 0.10518 & -2.97 & 0.004 & Signifikan \\
\hline
\end{tabular}

Kalimantan Timur adalah ARIMA $(0,1,[1,12])$. Bentuk umum model dapat dituliskan :

$(1-B)^{1} Z_{t}=\left(1-\theta_{1} B^{1}-\theta_{12} B^{12}\right) a_{t}$

Dari estimasi parameter yang telah dilakukan $Z_{t}=Z_{t-1}-0,4824 a_{t-1}+0,24697 a_{t-12}+a_{t}$

diketahui bahwa parameter model ARIMA $(0,1,[1,12])$ dan ARIMA $(1,1,[24])$ berpengaruh signifikan terhadap parameternya karena memiliki P-value yang nilainya $<(\alpha=0,05)$. Setelah dilakukan uji signifikansi, dilakukan pemeriksaan asumsi white noise dan distribusi normal yang akan ditunjukkan pada Tabel 5.3.

Table 3 Pemeriksaan White Noise dan Residual Distribusi Normal

\begin{tabular}{|c|c|c|c|c|}
\hline Model & \multicolumn{3}{|c|}{ White Noise (WN) } & $\begin{array}{c}\text { Normal } \\
\text { itas } \\
(p- \\
\text { value })\end{array}$ \\
\cline { 2 - 5 } & Lag & P-value & Kesimpulan & \\
\hline ARIMA & 6 & 0.2018 & Memenuhi & $>0.150$ \\
\cline { 2 - 4 }$(0,1,[1,12])$ & 12 & 0.4917 & Memenuhi & \\
\cline { 2 - 4 } & 18 & 0.7432 & Memenuhi & \\
\cline { 2 - 4 } & 24 & 0.3550 & Memenuhi & \\
\hline
\end{tabular}

Table 4 Pemeriksaan White Noise dan Residual Distribusi Normal (Lanjutan)

\begin{tabular}{|l|r|r|l|l|}
\hline ARIMA & 6 & 0.1603 & Memenuhi & \multirow{2}{*}{$>0.1500$} \\
\cline { 2 - 4 }$(1,1,[24])$ & 12 & 0.1223 & Memenuhi & \\
\cline { 2 - 4 } & 18 & 0.3419 & Memenuhi & \\
\cline { 2 - 4 } & 24 & 0.3681 & Memenuhi & \\
\hline
\end{tabular}

Dari hasil pemeriksanaan asumsi white noise dan distribusi normal, maka model yang diduga (ARIMA $(0,1,[1,12])$ dan ARIMA $(1,1,[24]))$ untuk meramalkan nilai ekspor non migas telah memenuhi asumsi residualnya. Hal ini karena pada pengujian asumsi, model tersebut memiliki nilai P-Value yang lebih besar dari $\alpha(0,05)$. Dua model ini selanjutnya akan dibandingkan untuk meramalkan data Ekspor Non Migas dengan mencari nilai sMAPE dan RMSE pada data outsample. Berikut merupakan nilai kriteria kebaikan model yang bisa dilihat dari nilai sMAPE, dan RMSE.

Table 5 Penentuan Model Terbaik Data Outsample

\begin{tabular}{|c|c|c|}
\hline Model & sMAPE & RMSE \\
\hline ARIMA (0,1,[1,12]) & $\mathbf{1 7 . 3 8 7 2 4}$ & $\mathbf{2 0 3 . 7 7 5 4}$ \\
\hline ARIMA (1,1,[24]) & 18.31621 & 225.7532 \\
\hline
\end{tabular}

Berdasarkan kriteria untuk menentukan model terbaik menggunakan sMAPE dan RMSE dapat diketahui bahwa model ARIMA yang paling baik untuk meramalkan data Ekspor non migas di

Selanjutnya data out sample nilai non migas di Kalimantan Timur akan dibandingkan dengan hasil ramalan data outsample:

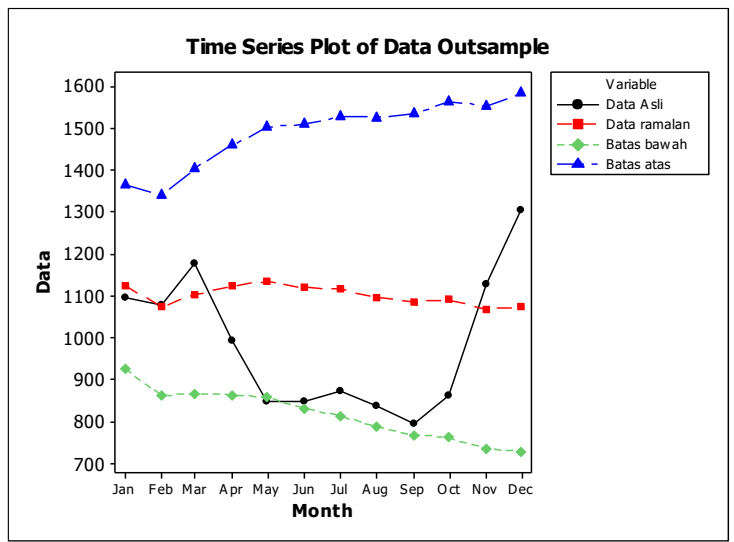

Gambar 9 Perbandingan Data Outsample dan Hasil Ramalan

Berdasarkan perbandingan antara data outsample dan data ramalan dapat diketahui bahwa hasil ramalan menggunakan model ARIMA ternyata belum bisa menangkap pola data dengan baik apabila terdapat perubahan ekstrim dari data. Hal ini dapat dilihat dari plot yang berwarna hitam dan merah masih memiliki perbedaan, namun hasil analisis menunjukan bahwa data outsample masih berada pada range batas atas dan bawah hasil ramalan sehingga model tersebut masih dapat digunakan untuk meramalkan data Ekspor non migas beberapa periode bulan ke depan. Hasil ramalan data ekspor untuk 5 bulan dapat diketahui sebagai berikut:

Table 6 Peramalan Data Ekspor Bulan Januari-Mei 2021

\begin{tabular}{|l|r|r|r|}
\hline & \multicolumn{1}{|c|}{ Batas Bawah } & Hasil Ramalan & \multicolumn{1}{c|}{ Batas Atas } \\
\hline Januari 2021 & 959.09 & 1180.21 & 1452.34 \\
\hline Febuari 2021 & 926.71 & 1183.71 & 1511.99 \\
\hline Maret 2021 & 910.16 & 1200.76 & 1584.14 \\
\hline Aril 2021 & 854.39 & 1160.27 & 1575.66 \\
\hline Mei 2021 & 793.67 & 1106.66 & 1543.09 \\
\hline
\end{tabular}

Hasil visualiasasi peramalan data Ekspor Non Migas di Kalimantan Timur dapat disajikan pada Gambar berikut:

Farida Nur Hayati ${ }^{1}$, Diana Nurlaily ${ }^{2}$, Elly Pusporani ${ }^{3} /$

J Statistika Vol. 14, No. 2, (2021) 


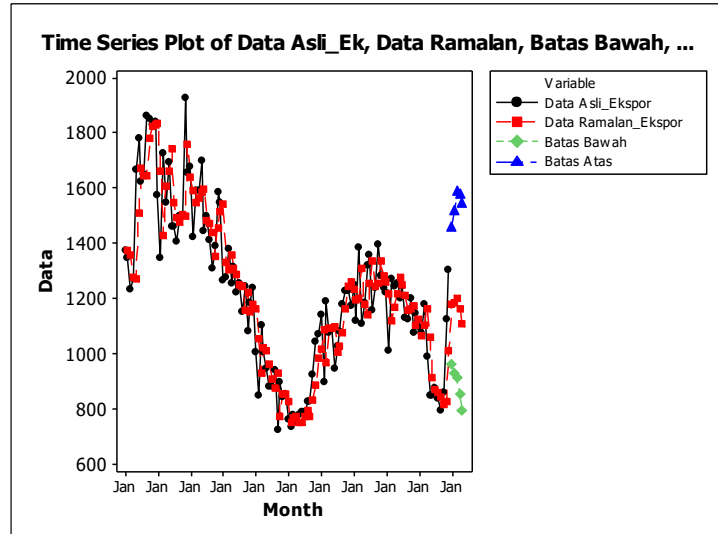

Gambar 10 Perbandingan Data Ekspor Non Migas dan Hasil Ramalan

Berdasarkan plot pada Gambar 10 yang menunjukkan perbandingan antara data aktual dan data ramalan dapat diketahui bahwa hasil ramalan sudah bisa menangkap pola data dengan baik. Hal itu terlihat dari plot berwarna hitam dan merah yang saling berhimpit.

\section{KESIMPULAN DAN SARAN}

Hasil penelitian peramalan data Ekspor Non Migas di Kalimantan Timur menggunakan metode ARIMA diperoleh kesimpulan yaitu:

1. Model ARIMA $(0,1,[1,12])$ merupakan model yang paling baik untuk meramalkan data Ekspor non migas di Kalimantan Timur karena memiliki nilai sMAPE dan RMSE yang minimum. Bentuk umum model dapat dituliskan :

$Z_{t}=Z_{t-1}-0,4824 a_{t-1}+0,24697 a_{t-12}+a_{t}$

2. Dari hasil perbandingan antara data aktual dan data ramalan dapat diketahui bahwa hasil ramalan sudah bisa menangkap pola data dengan baik karena plot nya yang saling berhimpit.

\section{DAFTAR PUSTAKA}

Amalina, N. (2016). Penerapan Metode Artificial Neural Network untuk Meramalkan Nilai Ekspor Migas dan Non Migas di Indonesia. Surabaya: Institut Teknologi Sepuluh Nopember.

Badan Pusat Statistika. (2020). Analisis Komoditas Ekspor 2013-2020. Jakarta: Badan Pusat Statistika.
Daniel, W. W. (1989). Statistik Nonparemetrik Terapan. Jakarta: PT Gramedia.

Gooijer, J. D., \& Hyndman, R. J. (2006). 25 Yesrs of Time Series Forcasting. Journal of Forecasting, vol 22 no 443-473.

Hartati. (2017). Penggunaan Metode ARIMA Dalam Meramal Pergeraka Inflasi. Jurnal Matematika, Sains, dan Teknologi, 1-10.

Huda, S. (2006). Analisis Beberapa Faktor yang Mempengaruhi Ekspor Non Migas Indonesia ke Jepang. Jurnal Ilmu-ilmu Ekonomi, 117-224.

Lestari, E., Widiharih, T., \& Rahmawati, R. (2018). Peramalan Ekspor Nonmigas dengan variasi Kalender Islam Menggunakan X-13 ARIMA SEATS. Jurnal Gaussian , 236247.

Nurmawaddah, S. (2019). Pengaruh Ekspor Non Migas Terhadap Pertumbuhan Ekonomi Provinsi Kalimantan TImur. . Akuntabel, 1228-1333.

Ruslan, R., Harahap, A. S., \& Sembiring, P. (2013). Peramalan Nilai Ekspor di Provinsi Sumatera Utara dengan Metode ARIMA Box-Jenikins. Saintia Matematika, 579589.

Wardhana, A. (2011). Analisis Faktor-Faktor yang Mempengaruhi Ekspor Non Migas Indonesia ke Singapura Tahun 1990-2010. Jurnal Manajemen Akutansi, 99-102.

Wei, W. (2006). Time Series Analysis Univariate and Multivariate Methods (2nd ed.). New Jersey: Pearson Education Inc. 